\title{
Challenging Life of Women in Namita Gokhale's the Book of Shadows
}

\author{
P. Priyadharshini, S. Mohan
}

\begin{abstract}
Today the world is running after the money and the people are thinking that money makes everything. Comparing to men, women are giving extra important for money more than men and not only for the purpose of spending money for charity, but also for luxurious life. In their daily life money and luxurious life are valuable for them. In Namita Gokhale's "The Book of Shadows" shows the importance of human life and also shows the needs of the women in their day-to-day life. Rachita is the main character, she is a good-looking woman and also a lecturer and earning more money. But unfortunately, she meets an accident and lost her beauty. So she is not ready to face the people, in the college and also the society. And then Rachita's life is totally changed, and started to live with what she is having. She does not expect anything more in her life.
\end{abstract}

Keywords: Alienation, corporal illness, loneliness, problem facing, skills for lead life, money and beauty.

\section{INTRODUCTION}

In the modern world money and beauty, both are important things. While comparing to men, the girls are giving more important for the money and also for their luxurious life. Some women are earning money, for only beautify their visage. A few women in the town side area, they totally addicted to makeup and money. And the women thinking that they cannot live or survive in the world, without beautifying themselves and without money. But their inner soul knows that the beauty and the money only are not important, but they cannot accept that from their normal life and their inner soul does not accept the reality.

\section{CHALLENGES AND GROWTH}

For women, there is no satisfaction in earning money and also not satisfying in buying things for their daily use for beautifying their body. They want more income and more new products and they will not say 'no' to this increment. Namita Gokhale clearly expresses in her novel "The Book of shadows", the heroine Rachita Tiwari's life shows the importance of money plays an essential role of beautifying oneself but it doesn't not peace the mind. The women are have to challenge their problem by their own self.

Revised Manuscript Received on December 20, 2019.

* Correspondence Author

Ms. P. Priyadharshini*, Department of English, Kalasalingam Academy of Research and Education, Krishnankoil, India. Priya22priya12@gmail.com

Dr. S. Mohan*, Department of English, Kalasalingam Academy of Research and Education, Krishnankoil, India. Email: smoha001@gmail.com

\section{III.METHODOLOGY}

\section{A. Rachita and her Acid Attack}

In the novel, Namita Gokhale tells not only the life of Rachita in Ranikhet but also the theme of the novel is that the money and beauty are not important for the life, but peace is more important for a person. So Gokhale tells that Rachita is a normal and beautiful woman, but unfortunately, she lost the beauty of her face, so she tries to overcome from the pain. She searches peace and she finds that the village is the only place to find peace in her mind. This is the place where she spent her childhood life.

For her, money does not give any peace to her mind only nature gives her the wonderful peace, what she is searching. Both the money and the beauty will not give peace.

\section{B. Alienation}

When Rachita was working as a lecturer in college, she has enough money and also she looked beautiful. But she did not have any peace in her mind. And then she lost her beauty because of the acid attack by her husband's sister. And then came to the village where she spends her childhood time. There she lives with peace of mind without beauty and enough money. When she is in the town she uses to cover her appearance because the people are teasing her facial appearance. She is telling,

I put on my walking shoes, and covering my face with a muslin chunni, set off on a long walk. I go past the tennis court to the meadow where the marigolds bloom, to the spot near the stream which is my private refuge against the unexpected. I lie down on the damp earth and the sky above, and nothing has ever changed in my world. (The Book of Shadows17)

\section{Taciturn life}

After her acid attack she suffers very much and she is not even ready to touch her face. And she is not ready to see her face on the mirror. The acid attack changes her life totally. Her face does not show any difference in smile and anger. She loses her beauty because of the acid attack and also she lost her confidence. But she is ready to change her mindset, which she really wants to face the society with her injured face. But she cannot change herself and she wants some peace in her mind and also she wants some time to overcome from the shock of that accident. 
While in hospital, recovering from the shock of the acid attack, from that hideous moment when Anand's sister had clutched my arm somewhere above the elbow and splashed the burning mess of hate and pain and unappeasable anger upon my face, after she had damaged and changed my life forever, I had awoken from the dull flatulent half-life of anesthesia. (TBS 20)

\section{Faceless Life of Rachita}

Then she is moving to the Ranikhet village to peace her mind. Naturally doing some work busily make a person to forget the past events, so she is following the same trick to forget all the horrible past event, Rachita changes her life in a busy schedule and she tries to forget all the past and also she tries to forgive Anand's sister.

I have started on the old journal which Lohaniju has given me. The paper has aged only slightly, it is still crisp, and the ink has not faded at all. The handwriting, in spite of it's old-fashioned flourished, is in simple running hand, and not in the least difficult to decipher. (TBS 33)

At the beginning of her accident, she becomes silent because she lost the beauty of her face. And also she thinks that silence is the only solution to make her peace. Many people are thinking that the silence is the best medicine for the problem but they don't think about anything and always be silent for anything. That makes her to live unaccompanied by anyone in society. And also she is not prepared to go to college and face the students. And she thinks that only silence is the best solution for every problem. But she does not like to be in silent and she wants to forget all and tries to change her life from silence. Because she knows that silence does not always give strength. So she wants to change her troubling silent life, she is breaking her silent,to go through the Ranikhet.

Perhaps silence is indeed better. That's what the ancient Vedas say. Mauna servant sadhana”.Silence is always the best option. But I've been silents much too long, with no one to amused with wagging...(TBS 13)

But anyway her money and beauty do not give any peace and solace to her and she finds the peace from only by nature and Lohaniju, not from painting her face and polishing her nails. She does not even look her face on the mirror even though she feels unhappy. The beauty and the money do not give her a new life, from the accident. Only her own changes, for her life, give solution to all the problems and make her to enjoy her life, with her old books, nature of the Ranikhet and stories by Lohaniju.

People who have injured in their body naturally have some disturbance in their mind. But their injury will not be changed, but they can change their wish and she needs some changes to enhance her own life. Because she cannot expect other people will come and help all the time, for the entire problem. And their mental illness leads to alienation. Living alone in life is very horrible. And that makes them to think differently and also they do not mingle with others. After Rachita's accident on her face, she is not able to face people and she starts to avoid other people even her friends and also the collegemates. I lie down on the damp earth and the sky above, and nothing has ever changed in my world. (TBS 17)

\section{E. Fact of Life}

And then she changes her loneliness in a different way. Then she starts to accompany the books and Lohaniju's stories. But her money and her beauty do not accompany her. The women should think about life and they should know the value of their life. Earning money is not important but life has a lot of lesson to learn.

"I looked the mirror..." you have no concept of the scope and import of these words. I looked at the mirror, and, for the first time in a month, I saw my face. You will make allowances for the fact that it was dark in the dressing room, that the mirror itself was only notionally a reflector of the true image, but the point of the encounter was that looked fine- quite nice really. (TBS 218)

In human life, there are more troubles one has to face, escaping from the trouble will not give the solution. So the people have to overcome the problem with the correct solution. Here Rachita also tries to overcome the problem, she does not think about the same problem and wasted her life. But she takes some time to overcome the problem. And money is not the solution for all the problems and the beauty will not give life again. So nothing is permanent in human life, everything is changeable. she has the confidence in life and she knows that confidence is the only solution to overcome from the troubled life. And the confidence only makes her to change her life.

\section{F. Believe in Yourself and Rise}

There are many people living in the world with many problems. The problems are different from one people to another. All the people are not having the same problem but some people are finding ways to overcome the problem but some people are not thinking about the solution to the problem but they only thinking about the problem. But the people have to think about the solution to the problem. Here Rachita is not only thinking about the problem but her thinking paves ways to overcome the problem. But many people take revenge by make others to suffer a lot. And they live a happy life without experiencing any problem. They create a new problem in a new way. Rachita is making her mind peace not by making others to suffer. But she lives to peace her mind by reading books and hearing stories by Lohaniju. And she likes to spend more time on books and nature more than the neighbors.

\section{IV.CONCLUSION}

The entire problem has solution and the solution should not harm others. But the people are not thinking the solution to the problem when they are facing the problem. They lose their confidence at first. Some people over thinking about the problem that make them physically affect. The people have to clearly know that the problems come to life but they are not stable. 
Rachita feels very badly by experiencing the problem. She is thinking about the problem then she thinks about her future life and changing herself. And she is not going to attempt any wrong decision in her life. She takes a good decision and changes her life in a successful manner.

Life has many troubles. So we have to overcome the problem and trouble. We learn something when we come across the problem. So try to learn from the problem. When start to live alone then nobody hurt but the living alone should not be continued over the life.

The theme of revenge is the main part of the novel that Anand's sister mistakenly thinking that her brother died because of Rachita. Then she shows her revenge to Rachita by throwing acid on her face. But Rachita does not show any revenge attitude towards anyone. But she suffers very much because of her face and pain of the acid attack. Instead of taking revenge she feels scared by Anand's sister. In the novel there are many themes given namely love, revenge, confidence, nature, pain, money, beauty, etc... all the themes are closely related in this novel.

\section{REFERENCES}

1. Gokhale, Namita 'The Book of Shadows' New Delhi: Penguin Books India Pvt. Ltd. 2001

2. Venkadaram K. 'A spirited Effort'. Indian Reviews of Books, dec-jan,2000.

3. Mukherjee S, Mukhopahyay DK. Stigma tpwards mental illness: A hospital based cross- sectional studies among caregiver in West Bengal. Indian J health 2018: 62:15-20.

4. Mitra S, Sankar AP, Holder D, Saren AB, LOS, Sarkar GN, correlation among perceived sree emotional intelligence, and burnout of resident doctors in a medical college of Bengal: A mediation analysis. India J public health 2018: 62:27-31.

5. Jung, C.G Aspects of feminine. London: Rouledge and Keegan Paul,1982.

\section{AUTHORS PROFILE}

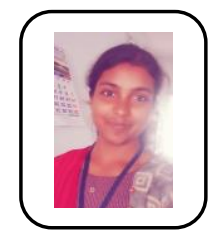

Ms. P.Priyadharshini has completed her B.A., M.A., and pursuing her $\mathrm{Ph} . \mathrm{D}$ in full-time at Kalasalingam Academy of Research and Education under the guidance of Dr. S. Mohan. She is doing her research in Indian Writing in English.

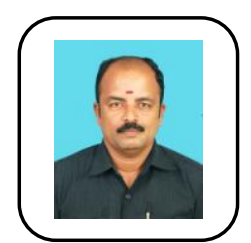

Dr. S. Mohan is an Associate Professor of the English Department at Kalasalingam Academy of Research and Education, Krishnankoil, Tamilnadu, India and is serving as Associate and Editorial Board member in more than eight International Journals. His areas of interest and research are in World Literatures, English Language Teaching and his main research area is African American Literature, which he formalized in his $\mathrm{PhD}$ (2013) on this subject. He has taught British, American, Indian Literatures and Literary Criticism in Post Graduate and Pre Doctoral Degree. He also taught Communicative English, English for Technical Communication for engineering graduates. He has presented papers at conferences, published articles and papers in various International journals. He has produced more than 25 M.Phil scholars and $04 \mathrm{PhD}$ scholars are pursuing their research under his guidance. 